\title{
Organization Justice, Support and Trust: Evidence from Saudi Companies
}

\author{
Mourad Mansour
}

\begin{abstract}
A considerable number of studies have investigated the relationship between perceptions of organizational justice and employees' work attitude. This study investigates the effect of distributive justice, procedural justice and interactional justice on supervisor support, organization support, supervisor trust and organization trust in Saudi companies. A questionnaire was used to assess the different relationships. Different results were found confirming or rejecting the different hypotheses.
\end{abstract}

Index Terms-Organizational justice, supervisor, Saudi Arabia.

\section{INTRODUCTION}

Social exchange theory has been discussed widely in different disciplines including sociology and social psychology. It involves two important facets - trust and fairness [1]. Research has investigated the relationship between perceptions of organizational justice (distributive, interactional, and procedural) and employees' attitudes [2], [3].

The purpose of this paper is to understand the relationship between distributive justice, procedural justice, Interactional justice, organizational support, supervisor support, organizational trust, and supervisory trust in Saudi companies.

\section{LITERATURE REVIEW}

\section{A. Organizational Justice}

The "self-interest" model [4], suggests that people will pursue self-interest by maximizing their own resources based on their perception of fairness and justice. In order to enhance perceptions of distributive justice and maximizing Self-interest, individuals want to exert as much control over outcomes in order to boost the perception of distributive justice. Distributive justice is concerned with perceptions of fairness arising from organizational allocations and outcomes [5]. It is how the employee perceives fairness in the organization and how the organization is treating him equally regarding responsibilities and compensation. The preponderance of research indicates that employees' feelings of inequity (distributive justice) are associated with dissatisfaction regarding outcomes such as pay and promotion [6]-[7].

Procedural justice can be referred as the process and

Manuscript received March 24, 2013; revised May 30, 2013.

Mourad Mansour is with the King Fahd University of Petroleum and Minerals, Saudi Arabia (e-mail: mmansour@kfupm.edu.sa). procedures by perceptions of distributive justice are based significantly on comparisons with others [1], [8]-[10]. It is the process and procedures by which allocation decisions are made [1], [11]-[12]. The vital aspect in procedural justice is that the employee has a "voice" and input in the outcome even if it was an unpleasant and may cause dissatisfaction.

Interactional justice is how the employees are treated inside the organization by their superiors [13]. It involves less formalized aspects of interaction. It shows how the management is treating employees and this includes the degree of respect, honesty and understanding [13].

\section{B. Organizational/Supervisor Support}

Reference [14] defines "perceived organizational support" as "an employee's perception that the organization values his or her contribution and cares about the employee's wellbeing". Reference [15] state that "Perceived organizational support refers to the degree to which an individual believes that the organization cares about him/her, values his/her input and provides his/her with help and support". It is linked directly with three categories of favorable treatment received by employees, like rewards, good working conditions, fairness and supervisor support, in return favorable outcomes are achieved such as satisfaction and commitment.

Perceived supervisor support is how employees perceive their supervisors care for the wellbeing and their attitude toward them and the organization [16]. This topic have gained huge amount of attention in the literature and been significantly related to turnover and other outcomes in organizations [17]-[18].

\section{HYPOTHESES}

\section{A. Relationship between Organizational Justice and Support}

Researchers have reported a positive relationship between organization justice and support as employees perform citizenship behaviors to counter the fair treatment offered by organizations [18]-[24].

1) H1a: distributive justice is a positively related to Organizational support.

2) H1b: Procedural justice is a positively related to Organizational support.

3) H1c: Interactional justice is a positively related to Organizational support.

4) H2a: distributive justice is a positively related to supervisor support.

5) H2b: Procedural justice is a positively related to supervisor support. 
6) H2c: Interactional justice is a positively related to supervisor support.

\section{B. Relationship between Organizational Justice and Trust}

Perceptions of fairness (justice) are implied by trust and it will lead to trust in authorities [25]. Management must capitalize on trust to assure best performance. References [26]-[27] emphasize the significance of consistency. Research shows a positive relationship between organizational justice and trust in the supervisor [21], [28]-[29] and trust in the organization [29]-[31].

1) $\mathrm{H} 3 \mathrm{a}$ : distributive justice is a positively related to Organizational Trust (OT).

2) H3b: Procedural justice is a positively related to OT.

3) H3c: Interactional justice is a positively related to OT.

4) H4a: distributive justice is a positively related to Supervisory Trust (ST).

5) H4b: Procedural justice is a positively related to ST.

6) H4c: Interactional justice is a positively related to ST.

\section{Relationship between Organizational Support and Trust}

Organizational support and trust relationship will be tested.

1) H5a: Perceived organizational support (OS) is a positively related to Organizational trust (OT).

2) H5b: Perceived Supervisor support (SS) is a positively related to Supervisor trust (ST).

\section{Methodology}

The research was conducted through a questionnaire obtained from previous literature. It was developed to measure the different hypotheses. All questions used in the questionnaire have a 5 likert-type scaled ranging from "strongly disagree" (1) to "strongly agree" (5). A sample of 200 employees has been asked to take the survey representing public and private sector form every major industry in Saudi Arabia.

Table I shows the demographic analysis.

SPSS was used to perform the analysis on the sample in order to rest the given hypotheses first by measuring the reliability of the models as shown on Table II.

TABLE I: DEMOGRAHICS

\begin{tabular}{lcc}
\hline \hline Saudi & 136 & $68 \%$ \\
Non-Saudi & 64 & $32 \%$ \\
\hline \hline High School or Less & 31 & $15.5 \%$ \\
Diploma & 33 & $16.5 \%$ \\
Bachelor & 133 & $66.5 \%$ \\
Master & 3 & 1.5 \\
\hline \hline 3 years or Less experience & 40 & $20 \%$ \\
4 to 5 years & 26 & $13 \%$ \\
6 to 10 years & 26 & $13 \%$ \\
11 to 15 years & 15 & $7.5 \%$ \\
More than 15 years & 93 & $46.5 \%$ \\
\hline \hline 26 to 30 years old & 31 & $15.5 \%$ \\
31 to 35 & 34 & $17 \%$ \\
35 to 40 & 30 & $15 \%$ \\
More than 40 & 78 & $39 \%$ \\
\hline \hline
\end{tabular}

TABLE II: RELIABILTY ANALYSIS

\begin{tabular}{ll}
\hline \hline Distributive justice & .732 \\
Procedural Justice & .833 \\
Interactional Justice & .903 \\
Organization support & .817 \\
Supervisor Support & .833 \\
Organizational Trust & .755 \\
Supervisor Trust & .712 \\
\hline \hline
\end{tabular}

\section{RESUlTS}

The following results were found:

1) H1a: distributive justice is positively related to Organizational support.

2) H1b: Procedural justice is not positively related to OS.

3) H1c: Interactional justice is positively related to OS.

4) H2a: distributive justice is not positively related to supervisor support.

5) H2b: Procedural justice is positively related to SS.

6) H2c: Interactional justice is positively related to SS.

7) $\mathrm{H} 3 \mathrm{a}$ : distributive justice is not positively related to Organizational Trust.

8) H3b: Procedural justice is not positively related to OT.

9) H3c: Interactional justice is positively related to OT.

10) H4a: distributive justice is not positively related to Supervisory Trust.

11) H4b: Procedural justice is positively related to ST.

12) H4c: Interactional justice is positively related to $S T$.

13) H5a: Perceived organizational support (OS) is positively related to Organizational trust (OT).

14) H5b: Perceived Supervisor support (SS) is positively related to Supervisor trust (ST).

\section{A. Relationship between Organizational Justice and Organizational Support}

The relationship of the distributive justice and organization support is positive which indicates that employees perception of fairness is directly related to their perception that the organization seeks their goodwill; if the organization is fair in pay, rewards and assigning tasks to employees, the employee will believe that the organization cares and supports him. If the organization doesn't treat employees fairly, it will directly build a negative image that may lead to employee turnover.

There is no positive relationship between procedural justice and perceived organization support. Employees don't see the allocation decisions as an indication that the organization caring for them and their contribution will not lead to the perception of the employee goodwill because is mainly directed to supervisor, the perceived organization support will not affect the perception of procedural justice because this perception is based on individuals like supervisors and managers not the overall organization.

The interactional justice is related to the perceived organization support, employees believe that the supervisor behavior toward them is the reflection of the organization support and care for their interest and goodwill. The supervisor behavior can reflect the organization culture because this supervisor is link to the higher management and decision makers, and believing that if the superiors treating 
us well, the organization treat us well.

\section{B. Relationship between Organizational Justice and Trust}

There is no positive relationship between both procedural and distributive justice and the organization trust. If there is a positive relationship between distributive justice and organization support the perception of fairness in pay, reward and assignments and the allocation of decisions do not necessarily build the trust of the employees toward the organization, because the employees think the organization support them at the current time but in the future still things are ambiguous for them; they will not trust the organization even if the organization seem to be fair or in their favor, they are cautious in this regard or they don't care for the organization.

It is also found that the interactional justice is positively related to organization trust, which means that employees believe that if the supervisor treat them well they will trust the organization even if the organization treat them fairly, and if the supervisor doesn't treat them fairly they will not trust the organization .

\section{Relationship between Organizational Justice and Supervisor Support}

Distributive justice is not positively related to supervisor support, the perception of fairness is not related to supervisor attitude even though it's related to organization trust. Procedural justice is positively related to supervisor support, the employees believe that the supervisor is looking in their interest and listen to them and understands their needs, cares for their input and contribution in the procedures, make the decisions biasedly, sense their needs, discuss implications of decisions of employees, offers justification to these decisions, and if they do so, by default the will perceive that he is supporting them, caring for them and looks for their wellbeing .

Interactional justice is positively related to supervisor support, if the supervisors respect the employees, treat them with integrity the employees will perceive that the supervisor supports, cares and cares for their wellbeing.

\section{Relationship between Organizational Justice and Supervisor Trust}

Supervisor trust is not related to distributive justice because the perception of fairness in pay and work schedule will not lead to trust because it is set by a higher authority than the supervisor, but it is positively related to procedural justice and interactional justice, i.e., the employees perceive that the supervisors listen to them and let them involved, respect them and treat them with kind and integrity and give up for their mistakes, otherwise if the supervisor doesn't treat the employees fairly and shows unprofessional and blame behaviors, the employees will not trust him.

\section{E. Relationship between Organizational Support and Organizational Trust}

The analysis showed a positive relationship between the organizational support and organizational trust means that if the organization cares for their employees opinions, looks for their wellbeing, strongly considers their goals and values, helps them if they need them, forgives their mistakes, they will believe that the organization has high integrity, honest, fair, trustworthy, and has good motives.

\section{F. Relationship between Supervisor Support and Supervisor Trust}

There is a positive relationship between perceived supervisor support and perceived supervisor trust, means that if the employees perceive that the supervisor cares about their opinions and inputs, really cares about their wellbeing, available for help if a problem occurs, willing for help at any cost, they will believe that the supervisor will treat them fairly, will never gain advantage of deceiving them, have the highest level of integrity, and the employees will be loyal and supportive to their supervisor .

The results of the analysis showed that the supervisor plays a vital role in the employee perceptions its related to perceived organization support by interactional justice, which means that the attitude of the supervisor may shape the perception of the organization support and the perception of organization trust, the organization must look for the behaviors of their supervisors in order to create the perception of organization justice.

\section{CONCLUSION}

Saudi companies should put a great effort in creating the best environment for their employees that enables them to achieve better results.

\section{ACKNOWLEDGMENT}

The author would like to express his thanks and appreciation for the support provided by KFUPM in the preparation of this paper.

\section{REFERENCES}

[1] J. B. DeConinck, "The effect of organizational justice, perceived organizational support, and perceived supervisor support on marketing employees' level of trust," Journal of Business Research, vol. 63, no. 12, pp. 1349-1355, 2010.

[2] Y. C. Charash and P. E. Spector, "The role of justice in organizations: A meta-analysis," Organizational Behavior and Human Decision Processes, 2001, vol. 86, pp. 278-321.

[3] J. A. Colquitt, D. E. Conlin, M. J. Wesson, O. L. H. Porter, and K. L. Ng, "Justice at the millennium: a meta-analytic review of 25 years of organizational justice research," Journal of Applied Psychology, vol. 86, no. 3, 425-445, 2001

[4] T. R. Tyler "Psychological models of the justice motive: Antecedents of distributive and procedural justice," Journal of personality and social psychology, vol. 67, no. 5, pp. 850-863, 1994.

[5] R. Pillai, E. S. Williams, and J. J. Tan, "Are the scales tipped in favour of procedural or distributive justice? An investigation of the USA, India, Germany, and Hong Kong," The International Journal of Conflict Management, vol. 12, no. 3, pp. 310-333, 2001.

[6] J. B. DeConinck and C. D. Stilwell, "Incorporating organizational justice, role states, pay satisfaction and supervisor in a model of turnover intentions," Journal of Business Research, vol. 57, no. 3, pp. 225-231, 2004.

[7] R. Folger and M. A. Konovsky, "Effects of procedural and distributive justice on reactions to pay decisions," Academy of Management Journal, vol. 32, no. 1, pp. 115-130, 1989.

[8] J. S. Adams, "Inequity in social exchange" in Advances in Social Psychology, L. Berkowitz, Ed., New York (NY): Academic Press: 1965, pp. 267-299.

[9] R. Cropanzano and J. Greenberg, Progress in organizational justice: Tunneling through the maze, in C. L. Cooper \& I. T. Robertson (Eds.), International review of industrial and organizational psychology, New York: Wiley, 1997, vol. 12, pp. 317-372. 
[10] J. Greenberg, "Reactions to procedural injustice in payment distributions: Do the means justify the ends?" Journal of Applied Psychology, vol. 72, no. 1, pp. 55-61, 1987.

[11] R. Folger and J. Greenberg, Procedural justice: an interpretive analysis of personnel systems, in K. Rowland \& G. Ferris (Eds.), Research in personnel and human resource management, Greenwich, CT: JAI Press, 1985, vol. 3, pp. 141-183.

[12] J. Thibaut and L. Walker, Procedural justice: A psychological analysis, Hillsdale, NJ: Lawrence Erlbaum Associates, 1975.

[13] R. J. Bies and J. F. Moag, Interactional Justice: Communication Fairness of Communication, in Research in negotiations in organizations, R. J. Lewicki, B. H. Shepard and M. H. Bazerman, Ed., Greenwich (CT): JAI Press, 1986, pp. 43-55

[14] R. Eisenberger, R. Huntington, S. Hutchinson, and D. Sowa, "Perceived organizational support," Journal of Applied Psychology, vol. 71, pp. 500-507, 1986.

[15] B. Erdogan and J. Enders, "Support from the top: supervisors' perceived organizational support as a moderator of leader-member exchange to satisfaction and performance relationships," Journal of Applied Psychology, vol. 92, pp. 321-330, 2007.

[16] C. P. M. Jr., R. W. Griffeth, N. S. Campbell, and D. G. Allen, "The effects of perceived organizational support and perceived supervisor support on employee turnover," Journal of Organizational Behavior, vol. 28 , no. 8, pp. 1059-1075, 2007

[17] R. Eisenberger, F. Stinglhamber, C. Vandenberghe, I. L. Sucharski, and L. Rhoades, "Perceived supervisor support: contributions to perceived organizational support and employee retention," Journal of Applied Psychology, vol. 87, no. 3, pp. 565-573, 2002.

[18] D. W. Organ, Organizational citizenship behavior: The good soldier syndrome, Lexington, MA: Lexington Books, 1988.

[19] D. W. Organ, "The motivational basis of organizational citizenship behavior," in B. M. Staw \& L. L. Cummings (Eds.), Research in Organizational Behavior, 1990, vol. 12, pp. 43-72: Greenwich, CT: JAI Press.

[20] J. Fahr, V. P. M. Podsako, and D. W. Organ, "Accounting for organizational citizenship behavior: Leader fairness and task scope versus satisfaction," Journal of Management, vol. 16, pp. 705-722, 1990.

[21] M. A. Konovsky and S. D. Pugh, "Citizenship behavior and exchange," Academy of Management Journal, vol. 37, no. 3, pp. 656-669, 1994.

[22] R. H. Moorman, "Relationship between organizational justice and organizational citizenship behaviors: Do fairness perceptions influence employee citizenship?" Journal of Applied Psychology, vol. 76, pp. $845-855,1991$

[23] R. H. Moorman, B. P. Niehoff, and D. W. Organ, "Treating employees fairly and organizational citizenship behavior: sorting the effects of job satisfaction, organizational commitment, and procedural justice,"
Employee Responsibilities and Rights Journal, vol. 6, no. 3, pp. 209-225, 1993.

[24] D. W. Organ and R. H. Moorman, "Fairness and organizational citizenship behavior: What are the connections?" Social Justice Research, vol. 6, pp. 5-18, 1993.

[25] J. Brockner and P. Siegel, "Understanding the interaction between procedural and distributive justice: the role of trust," in R.M. Cramer and T.R. Tyler (Eds.), Trust in organizations: Frontiers of theory and research, Thousand Oaks: CA, Sage, pp. 390-413, 1996.

[26] R. C. Mayer, J. H. Davis, and F. D. Schoorman, "An integrative model of organizational trust," Academy of Management Review 1995, vol. 20, pp. 709-734.

[27] G. S. Leventhal, "What should be done with equity theory?" in K. J. Gergen, M. S. Greenberg, and R. H. Willis (Eds.), Social exchange: Advances in theory and research, New York: Plenum, pp. 27-55.

[28] J. Camerrman, R. Cropanzano, and C. Vandenberghe, "The benefits of justice for temporary workers," Group Organization Management, vol. 32, no. 2, pp. 176-207, 2007.

[29] F. Stinglhamber, D. D. Cramer, and L. Mercken, "Perceived support as a mediator of the relationship between justice and trust," Group Organization Management, vol. 31, no. 4, pp. 442-468, 2006.

[30] S. Aryee and Z. X. Chen, "Countering the trend towards careerist orientation in the age of downsizing: Test of a social exchange model," Journal of Business Research, vol. 57, no. 4, pp. 321-328, 2004.

[31] S. Aryee, P. S. Budhwar, and Z. X. Chen, "Trust as a mediator of the relationship between organizational justice and work outcomes: Test of a social exchange model," Journal of Organizational Behavior, vol. 23 , no. 3, pp. 267-285, 2002

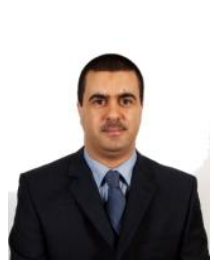

Mourad Mansour holds a Ph.D. degree in Management from the University of Tsukuba, Japan in 2003. He is an Assistant Professor in King Fahd University of Petroleum and Minerals, Department of Management and Marketing, College of Industrial Management, Saudi Arabia. He has taught Organizational Behavior, Principles of Management, Strategic Management and International Business. He has several articles published in refereed international journals. His main areas of research interest include: Job Satisfaction, Job Turnover, Employment of Disabled People, Job Performance, E-Business and E-Learning in the Workplace. He is a member of several organizations like the Academy of Management, Academy of International Business, Family Firm Institute, and Strategic Management Society. 